\title{
Alexander Kennedy Isbister (1822-1883)
}

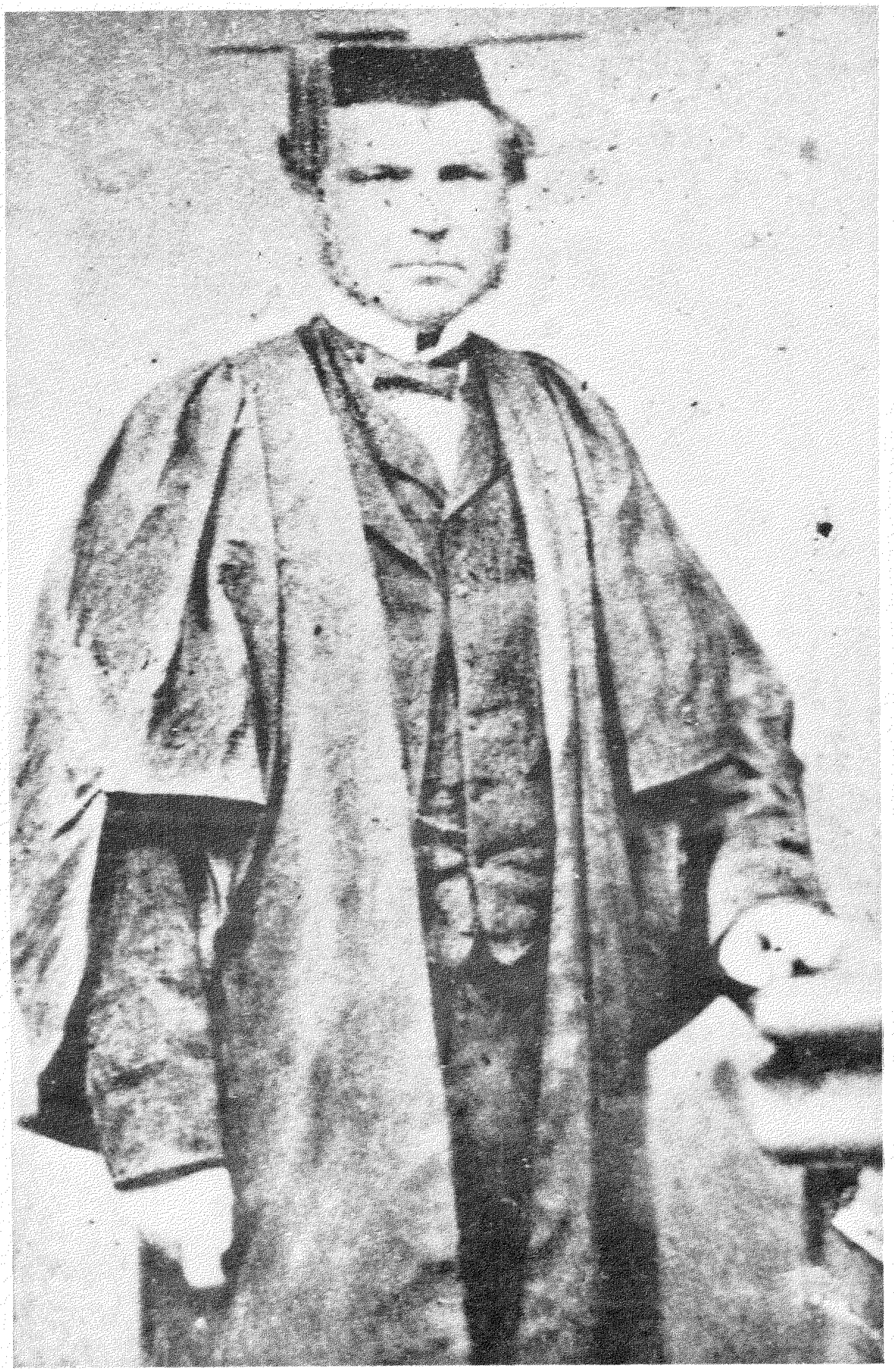

Courtesy of Manitoba Archives. 
As a committed and effective spokesman in London, England, for the poor indigenous people of mid-nineteenthcentury Rupert's Land - that is how Alexander Kennedy Isbister should be remembered by all Canadians and revered by those who were his people.

But he is not. Only one portrait of Alexander is known to exist, the photograph shown here. A few brief obituaries, magazine articles, and historical papers comprise the printed record. A short street in Winnipeg and a classroom building at the University of Manitoba are named after him. So are the Isbister Scholarships, although the money disbursed is no longer the return on Isbister's generous bequest to the university. This gift disappeared through embezzlement in 1914. The tangible record that remains, then, is slim, surprisingly so for a man who in his time was regarded as a great figure by the people of Red River.

Church records list Alexander Kennedy Isbister's grandmother on his mother's side as Agatha, an "Indian woman". His grandfather, Alexander Kennedy, hailed from the Orkneys and worked for the Hudson's Bay Company, as did Thomas Isbister, his father. Alexander was born in Cumberland House, as his mother had been, in June 1822, 48 years after this first HBC inland post was established by Samuel Hearne and in the same year that John Franklin and John Richardson visited the trading house on the return from their first visit to the Arctic.

As was done with many other offspring of the Company's personnel, young Alexander was sent away for his education: first, at ten to the Orkneys for a year or so of schooling and then in 1833 to the Red River settlement for more of the same. He was through at 16 and entered the service of the Hudson's Bay Company. Although he held his position as apprentice postmaster for only two years, these were to be the most formative of his life.

For the Company, Isbister travelled through the lower part of the Mackenzie Basin. When he left British North America in 1842 , barely 20 years old and never to return, he had acquired some valuable firsthand knowledge of the West and the North. More importantly, he had developed both an intense interest in the geology and geography of the land and a consuming compassion for its people.

In England, where Isbister established himself as a teacher, a writer of school textbooks, and later as a barrister, he made good use of the knowledge he had of what was then a still unknown country inhabited by largely forgotten Indians,
Métis, half-breeds, fur traders, and missionaries.

Two scientific papers, published in 1845 and 1855, form a solid base on which rests the reputation of Isbister as a pioneer geologist of northwestern Canada. In these treatises, he summarized all previous geological observations, added his own, and in 1855 provided a geological map on which the distribution of stratigraphic units is shown in much greater detail than on other contemporaneous maps, such as the one by John Richardson published in 1851 . He also recognized the importance of fossils or organic remains in the rocks "by which alone their relative ages and their true characters can be determined".

The native people of the West and Northwest do not owe their debt to Alexander Isbister merely for calling the attention of the British or even the internaiional scientific community to the physical characteristics of their country. That debt is owed mainly because young Alexander became an educated man attending King's College, Aberdeen, obtaining a Master of Arts degree from the University of Edinburgh and an L.L.B. from the University of London - and yet proudly maintained his ties with those he left behind. He was successful in what he undertook; he became a man of means. He provided an example of what others could aspire to, even though they would never come close to his achievements.

If not for himself, then for his people, Alexander earned his crown by his persistent battle against the injustices he saw being perpetrated by the Company. The battle began when, at age 25 , he became the trusted representative of petitioners who charged "that the Company impoverished the natives for their own profit". He never came to a halt. In 1871 shareholder A.K. Isbister took up a claim of the Chief Traders and Chief Factors at the General Court of the Hudson's Bay Company. By then he had become the leading authority on all matters affecting British North America. This distinction was not only well earned but also well deserved.

\section{FURTHER READINGS}

KNOX, H.C. 1957. Alexander Kennedy Isbister. Papers read before the Historical and Scientific Society of Manitoba. Series III, number 12: 17-28.

KUPSCH, W.O. 1977. Métis and proud. Geoscience Canada 4(3):147-148.

Walter O. Kupsch

319 Bate Crescent

Saskatoon, Saskatchewan, Canada

S7H 3 A6 